\title{
Bacteriological quality of water in private wells and boreholes in Makurdi Metropolis, Benue State, Nigeria
}

\author{
Ruth Adi Agyo (D), Raph Agbo Ofukwu, Anthony Ekle J. Okoh and Charity A. Agada \\ Department of Veterinary Public Health and Preventive Medicine, Federal University of Agriculture, Makurdi, Nigeria. \\ Corresponding author: Ruth Adi Agyo, e-mail: ruthagyo@gmail.com \\ Co-authors: RAO: ofukwu@hotmail.com, AEJO: profokohanthon45@gmail.com, CAA: caysla@gmail.com \\ Received: 06-12-2019, Accepted: 01-05-2020, Published online: 20-06-2020
}

doi: www.doi.org/10.14202/IJOH.2020.76-82 How to cite this article: Agyo RA, Ofukwu RA, Okoh AEJ, Agada CA (2020) Bacteriological quality of water in private wells and boreholes in Makurdi Metropolis, Benue State, Nigeria, Int. J. One Health, 6(1): 76-82.

\begin{abstract}
Aim: This study aimed at examined the presence of coliform bacteria in private wells and boreholes (BH) in peri-urban areas of Makurdi, Benue State, Nigeria, using the approaches of most probable number (MPN) index and coliform count.

Materials and Methods: Seven hundred and sixty-eight water samples were randomly collected during a 1-year period from non-cased wells, burn brick cased wells (BBW), concrete cased wells, and BH in four locations; A, B, C, and D during the wet and dry seasons. One liter of water was obtained from each well at every visit to the four sites, and eight water samples were collected from each visit. The samples were analyzed using multiple tube fermentation methods and pour plate techniques to determine the MPN of coliform/100 $\mathrm{ml}$ of water, reading from the MPN statistics table.

Results: One-way analysis of variance statistics was applied using Duncan's new multiple range test to separate the means where there was a significant difference. The result revealed that the MPN index and total coliform counts in all the wells in the locations were above the World Health Organization (WHO) permissible limit for potable water. The highest MPN index of 54.807 was recorded in Location A and followed by 42.679 in Location B. The MPN index in Locations C and $\mathrm{D}$ was 36.740 and 30.943 , respectively. There was significantly $(\mathrm{p}=0.000)$ higher total coliform count in the wet season $(41.48 \pm 7.09)$ than in the dry season $(38.33 \pm 2.83)$.
\end{abstract}

Conclusion: This study shows the presence of coliform bacteria isolates in all the wells and BH that exceeded the WHO permissible limits for drinking water. The water from these sources is unsafe for drinking except after dosing with appropriate germicides. Sensitization of the population on the actions they can take to make the water safe for domestic use is suggested.

Keywords: coliform, contamination, Enterobacteriaceae.

\section{Introduction}

Estimates from the World Health Organization (WHO) indicate that about 884 million people in the world still do not have access to drinking water from safe sources, and $89 \%$ of these people live in developing countries [1]. Lack of safe drinking water can have deleterious consequences and economic costs in morbidity, treatment, and death, particularly in Sub-Saharan Africa [2]. Diseases not limited only to cholera, typhoid, and the preventable hepatitis-A but also can occur as a result of the consumption of water contaminated with microbes [1-3], which may result in damage to liver, kidney, and heart [4,5]. In 2016 alone, the United Nations Children's Fund chronicled an average of 2500 fatalities on a daily basis in Nigeria occasioned by water-borne pathogens [2]. The Nigeria Centre for Disease Control recorded 42,466 cases of water-borne cholera from 20 out of 36 States

Copyright: Agyo, et al. This article is an open access article distributed under the terms of the Creative Commons Attribution 4.0 International License (http://creativecommons.org/licenses/ by/4.0/), which permits unrestricted use, distribution, and reproduction in any medium, provided you give appropriate credit to the original author(s) and the source, provide a link to the Creative Commons license, and indicate if changes were made. The Creative Commons Public Domain Dedication waiver (http:// creativecommons.org/ publicdomain/zero/1.0/) applies to the data made available in this article, unless otherwise stated. in 2017, which resulted in $830(1.95 \%)$ fatalities [5]. Estimates from the USAID [6] disclosed that about $52 \%$ of Nigerians in urban areas do not have access to improved drinking water supply and it get to as high as $78 \%$ in the rural areas. Even in urban areas, where large water bodies such as major rivers exist, like the River Benue, the populace still suffers a lack of potable water supply, even when the necessary water processing facilities have been installed [7]. A typical example is Benue State, it is one of the most populous states in Central Nigeria (about 600,000 inhabitants) [8] with its capital Makurdi suffering from acute shortages of safe and potable water supply [9]. This is despite the presence of the huge River Benue, which flows through 11 local government areas (LGAs) out of the 23 LGAs in the state [10]. The state capital, Makurdi, has an installed state-of-the-art water processing plant that can process $50,000 \mathrm{~m}^{3} /$ day, yet the inhabitants cannot access safe water [9].

The perennial water shortages have compelled the residents of Makurdi to seek alternative sources of water supply, and typically the groundwater resource is considered safer and tapped. The water extraction methods include, mostly, the digging of open well, which are either unlined with a casing or lined with burnt brick casing or concrete casing, while those with the resource sink shallow boreholes (SBH) [9]. 
However, there is evidence that water in the wells and SBH may not be as safe as it is perceived and might be contaminated by surface water sources with fecal material due to seepage and deep percolation into them $[9,11,12]$. The siting of the wells in places with peculiar geochemical attributes such as proximity to cemeteries and dumpsite is associated with the accumulation of elevated concentrations of undesirable pathogens in groundwater resources $[13,14]$. Studies have shown the presence of coliform bacteria in water from a large cross-sectional review of $\mathrm{BH}$ in Nigeria [10-14]. Coliform bacteria are prevalent in the environment and are typically harmless when they do not belong to the index of fecal pollution. The coliform group is made up of bacteria with distinct biochemical and growth qualities and some are associated with fecal contamination. The total coliform group is bacteria that multiply at ambient condition within the temperature range of $27^{\circ} \mathrm{C}$ while the thermotolerant or fecal coliform group is those that require higher temperatures in the region of $>42^{\circ} \mathrm{C}$ to grow and is distinctively of fecal origin [14]. The manifestation of any coliform bacteria in domestic water source, be it thermotolerant or otherwise, requires prompt inspection of the water for remediation. The existence of coliform bacterial in potable water is usually indicative that the water may be contaminated with germs, which might also be pathogenic [15]. Fecal coliform and Escherichia coli are bacteria whose presence indicates that the water is contaminated with human or animal wastes [13].
The presence of this fecal coliform in domestic water is thus a cause for concern from the public health perspective and necessitates the constant monitoring of the wells and assessing their bacteriological quality [16].

This study aimed to determine the bacteriological quality of water in private wells and BH in Makurdi Metropolis, Benue State, Nigeria.

\section{Materials and Methods}

\section{Ethical approval}

Ethical clearance was obtained from the College of Veterinary Medicine, Federal University of Agriculture, Makurdi (FUAM/CVM/ETHICS/003).

\section{Study area}

The study was conducted in Makurdi (Figure-1), the capital city of Benue State. It is situated on the flood plains of the lower Benue valley in NorthCentral Nigeria on latitude $7^{\circ} 53^{\prime} 44^{\prime \prime} \mathrm{N}$ and longitude $8^{\circ} 22^{\prime} 54^{\prime \prime}$ E. It covers a $10 \mathrm{~km}^{2}$ radius and the River Benue passed through Makurdi and split it in the north and south banks. Makurdi was stratified into four sections, South, North, East, and West, represented by Modern Market community (Location A), Federal Low-cost North Bank II community (Location B), Fiidi community (Location C), and Kanshio community (Location D).

\section{Sample collection and storage}

Water samples were randomly collected from the "locations" visited fortnightly for 12 months, beginning from October 2015 to September 2016. For each

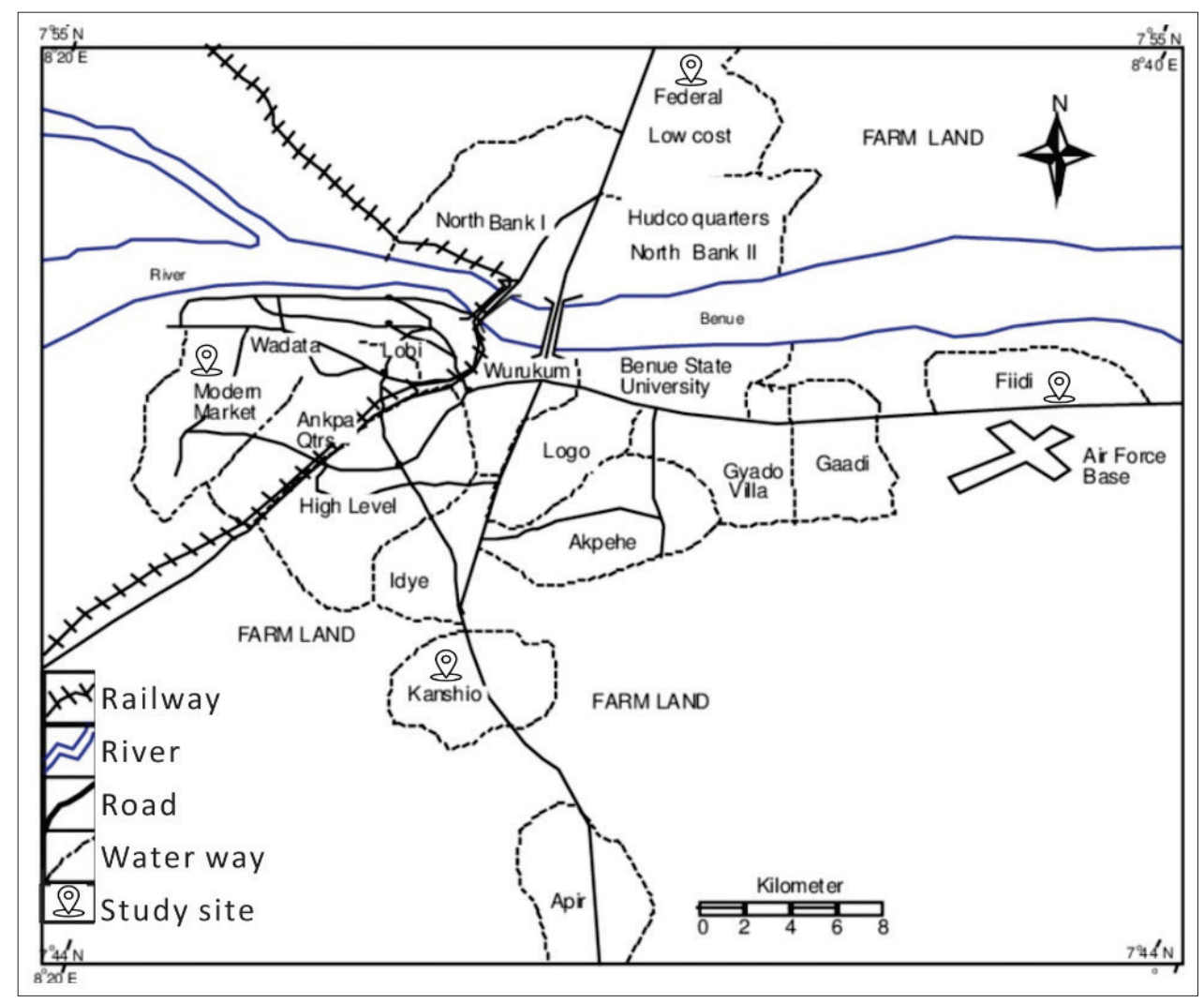

Figure-1: Map of the area of study [Source: Ministry of Land and Survey, Makurdi, Benue State, 2019]. 
"location," two wells each of non-cased wells (NCW), burnt brick cased wells (BBW), concrete cased wells (CCW), and shallow BH (SBH) (Figure-2) were randomly sampled. One liter of water was obtained from each well at every visit to the four sites, and eight water samples were collected for each visit. A total of 768 samples were collected in pre-cleaned $1 \mathrm{~L}$ plastic containers and put in icepacks, which were then taken to the laboratory for analysis. The water samples that were not analyzed immediately were stored in refrigeration at $4^{\circ} \mathrm{C}$ until processed and none of the samples were stored beyond the duration of 1 week.

\section{Water quality assessment for total coliform and fecal coliform counts}

Multiple tube fermentation method (Figure-3) was used to determine the most probable number (MPN) of coliform in the water sample. Three sets of five screw caped tubes in rack each containing 10 $\mathrm{ml}$ of MacConkey broth (oxide) and inverted Durham

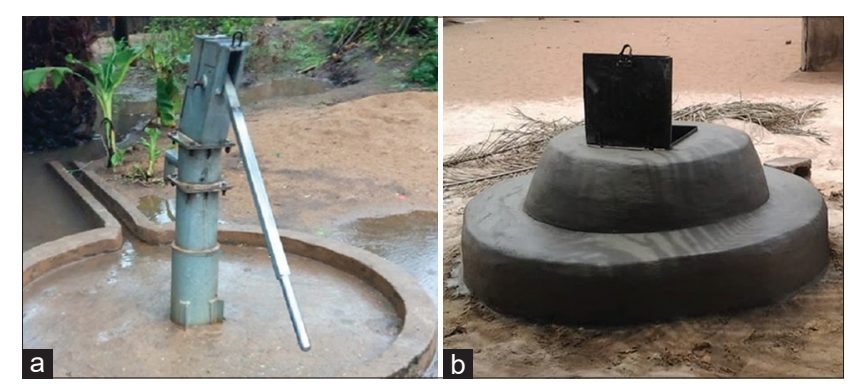

Figure-2: Some wells from which water samples were collected. (a) Borehole. (b) Concrete cased well.

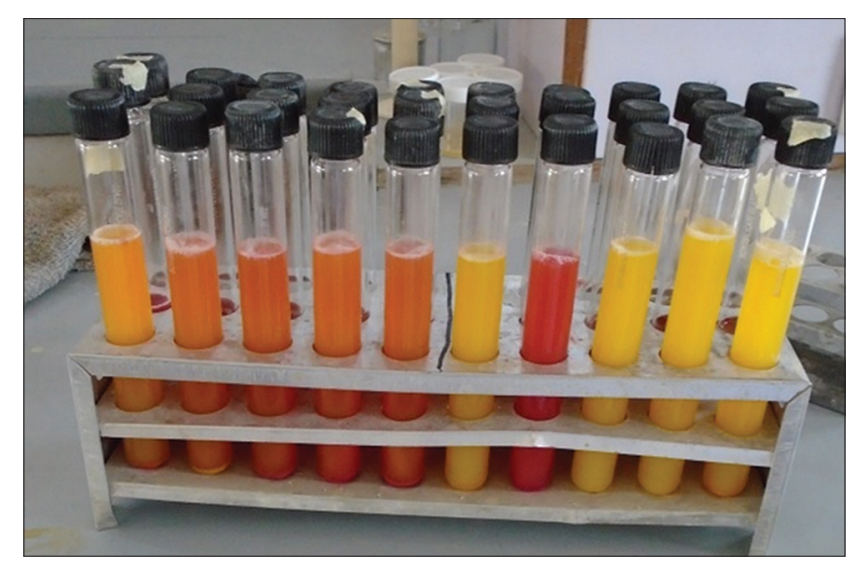

Figure-3: Multiple tube fermentation methods. vials were inoculated with $10 \mathrm{ml}, 1 \mathrm{ml}$, and $0.1 \mathrm{ml}$ of the water sample, respectively, according to standard methods. These were incubated at $35^{\circ} \mathrm{C}$ for $48 \mathrm{~h}$ and observed for the production of acids resulting in cloudiness (evidence of growth) and the evidence of gas production were regarded as positive for coliform. After enumeration, the number of positive tube combination from the set was used to determine the MPN of coliform $/ 100 \mathrm{ml}$ of water, reading from the MPN index table.

\section{Confirmatory test}

Detection of total coliforms and fecal coliforms was done by taking $1 \mathrm{ml}$ of broth from positive tubes with the smallest inoculum using sterile Pasteur pipette, into $10 \mathrm{ml}$ of $2 \%$ brilliant bacteria green lactose bile (Oxoid) in duplicates. These were incubated at $35^{\circ} \mathrm{C}$ and $44^{\circ} \mathrm{C}$, respectively, for $24-48$ $\mathrm{h}$ and observed for cloudiness and gas production. Tubes that were cloudy with gas production at both temperatures were considered confirmed positive for fecal coliforms, while those that showed growth with gas production were non-fecal coliforms.

\section{Completed test}

Organisms from positive confirmed tubes were isolated in pure culture on both eosin-methyl blue agar plates and incubated at $35^{\circ} \mathrm{C}$ for $48 \mathrm{~h}$. One or more typical colonies or colonies considered most likely to consist of coliform bacteria were picked and then tested for growth and gas production in MacConkey broth incubated at $35^{\circ} \mathrm{C}$ for $48 \mathrm{~h}$ and a negative reaction in the Gram stain.

\section{Statistical analysis}

The one-way analysis of variance at 5\% level of significance was used to compare means of the microbial water quality among all the samples from the wells in the different locations during the wet and dry season. The Duncan's new multiple range test was used to separate the means where there was a significant difference.

\section{Results}

\section{MPN index}

Variation in MPN index in the wells in a different location is shown in Table-1, and it shows significant variation in the MPN index for the type of

Table-1: Mean MPN index from sampled water in wells and boreholes from peri-urban areas of Makurdi (October 2015-September 2016).

\begin{tabular}{llcccc}
\hline Location & Factor & \multicolumn{3}{c}{ Type of well } & \multicolumn{2}{c}{$\begin{array}{c}\text { Total } \\
\text { mean }\end{array}$} & & $\begin{array}{c}\text { Uncased well } \\
\text { mean }\end{array}$ & $\begin{array}{c}\text { Shallow borehole } \\
\text { mean }\end{array}$ & $\begin{array}{c}\text { Burnt brick well } \\
\text { mean }\end{array}$ & $\begin{array}{c}\text { Concrete case well } \\
\text { mean }\end{array}$ \\
\hline A & MPN index & $97.708^{\mathrm{b}}$ & $12.375^{\mathrm{a}}$ & $60.521^{\mathrm{a}}$ & $48.625^{\mathrm{a}}$ \\
B & MPN index & 67.9167 & 10.687 & $50.833^{\mathrm{a}}$ & 54.807 \\
C & MPN index & 57.188 & 9.188 & $44.646^{\mathrm{a}}$ & 42.354 \\
D & MPN index & 47.771 & 8.146 & $37.333^{\mathrm{b}}$ & 35.938 \\
& Mean & 67.65 & 10.10 & 48.33 & 30.521 \\
\hline
\end{tabular}

Values are mean \pm SEM, $n=192$, Rows with different superscripts are significantly different at $p \leq 0.05$, asignificantly increased with reference to the dry season value, bSignificantly decreased with reference to dry season value, $A=M o d e r n$ Market community, $\mathrm{B}=$ North bank community, $\mathrm{C}=$ Kanshio community, $\mathrm{D}=$ Fiidi community 
well, location, and seasonality $(\mathrm{p}<0.05)$. The highest MPN index of 54.807 was recorded in Location A and followed by 42.679 in Location B. The MPN index in Locations C and D were 36.740 and 30.943, respectively. With regard to the type of well, the highest index was in the NCW (67.65) followed by in the BBW (48.33) and then the CCW. The SBH (10.10) recorded the least MPN index. The seasonal variation in MPN index is shown in Table- 2 and it shows that all the rainy MPN index of $62.40 \pm 12.75,44.55 \pm 5.89$, $38.16 \pm 5.25$, and $31.94 \pm 4.48$ were higher than the dry season index of $47.22 \pm 3.41,40.84 \pm 3.00,35.32 \pm 2.69$, and $29.95 \pm 2.10$ obtained in NCW, SBH, BBW, and $\mathrm{CCW}$, respectively. The wet season grand mean index of $41.48 \pm 7.09$ was significantly higher than the dry season's index of $38.33 \pm 2.80(\mathrm{p}<0.05)$.

\section{Coliform count (C)}

Table- 3 contains the result of the coliform count $\left(\mathrm{CFU} \times 10^{5}\right)$ count in water from the wells in the various locations during the wet and dry season. It shows that coliform count in Locations A, B, C, and D was $57.963,50.052,46.432$, and 44.823, respectively. All the recorded counts exceeded the WHO limit for coliform bacteria in potable water. The variation of coliform counts based on well type reveals that it was $72.42,15.17,59.63$, and 49.05 in NCW, BH, BBW, and $\mathrm{CCW}$, respectively, and these values are also above the WHO limits.

The grand mean seasonal variation of the coliform count $\left(\mathrm{CFU} \times 10^{5}\right)$ is shown in Table-4, and it shows that there was a significantly higher coliform count in the rainy season $(41.48 \pm 7.09)$ than in the dry season $(38.33 \pm 2.83)$. The coliform count in Location A was $60.69 \pm 1.02$ in the dry and $55.24 \pm 3.20$ in the rainy season. In Location B, it was $47.04 \pm 2.43$ in the dry season and $53.06 \pm 2.92$ in the rains while in Location $C$, it was $47.41 \pm 0.80$ in the dry season and $45.46 \pm 1.76$ in the rainy season. The coliform count in Location D was $45.14 \pm 2.45$ in the dry season and $38.51 \pm 1.61$ in the rainy season. The seasonal coliform counts in both seasons exceeded the WHO standard for potable water.

With respect to the wells, the coliform count in the wells, NCW was $56.04 \pm 3.91$ in the dry season and $79.25 \pm 15.15$ in the rainy season, in $\mathrm{BH}$, it was $8.69 \pm 0.67$ and $11.31 \pm 2.24$ in the dry and rainy seasons, respectively. Furthermore, the count in BBW was $48.54 \pm 3.68$ in the dry season and $37.18 \pm 6.29$ in the rains while CCW had counts of $40.06 \pm 3.04$ and $38.16 \pm 4.68$ for the dry and rainy seasons, respectively. $\mathrm{NCW}$ and $\mathrm{BH}$ exhibited the highest mean coliform count during the rainy season than the dry season, while BBW and CCW have higher counts of coliform in the dry season than in the rainy season.

\section{Factors affecting the MPN index and total coliform counts of water samples}

The result of the factors affecting the MPN index and coliform count of water in Makurdi peri-urban

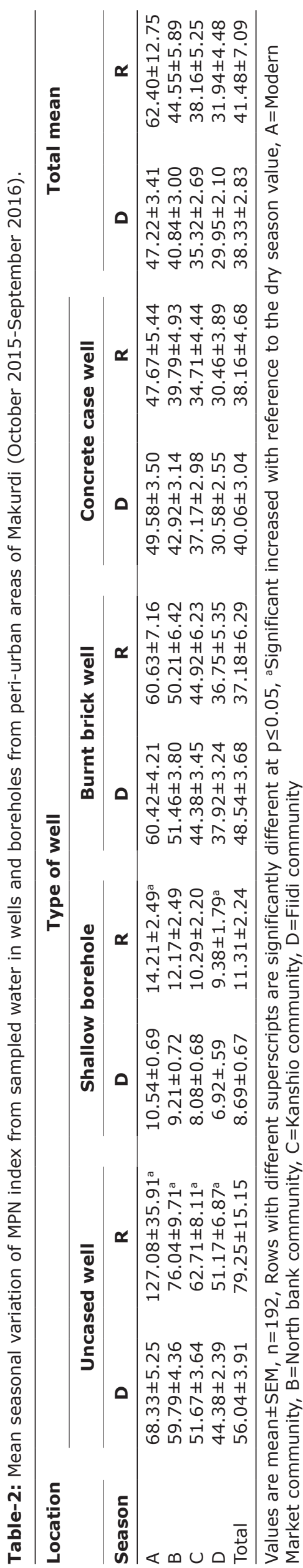

International Journal of One Health, EISSN: 2455-8931 
Table-3: Mean colony-forming unit $\left(\mathrm{CFU} \times 10^{5}\right)$ in sampled water from wells and boreholes in peri-urban areas of Makurdi (October 2015-September 2016).

\begin{tabular}{llccccc}
\hline Location & Factor & \multicolumn{2}{c}{ Type of well } & $\begin{array}{c}\text { Total } \\
\text { mean (\%) }\end{array}$ \\
\cline { 3 - 6 } & & $\begin{array}{c}\text { Uncased well } \\
\text { mean (\%) }\end{array}$ & $\begin{array}{c}\text { Shallow borehole } \\
\text { mean (\%) }\end{array}$ & $\begin{array}{c}\text { Burnt brick well } \\
\text { mean (\%) }\end{array}$ & $\begin{array}{c}\text { Concrete cased } \\
\text { well mean (\%) }\end{array}$ & \\
\hline $\mathrm{A}$ & $\mathrm{CFU} \times 10^{5}$ & $80.146(34.57)$ & $12.938(5.58)$ & $75.875(32.73)$ & $62.896(27.13)$ & $57.963(100.0)$ \\
$\mathrm{B}$ & $\mathrm{CFU} \times 10^{5}$ & $77.2083(38.56)$ & $12.1875(6.09)$ & $52.7708(26.36)$ & $58.0417(28.99)$ & $50.052(100.0)$ \\
$\mathrm{C}$ & $\mathrm{CFU} \times 10^{5}$ & $70.000(37.69)$ & $11.5833(6.24)$ & $61.667(33.2)$ & $42.479(22.87)$ & $46.432(100.0)$ \\
$\mathrm{D}$ & $\mathrm{CFU} \times 10^{5}$ & $62.333(37.260)$ & $23.979(14.330)$ & $48.188(28.800)$ & $32.792(19.600)$ & $44.823(100.0)$ \\
& Mean & $72.42(36.90)$ & $15.17(7.73)$ & $59.63(30.38)$ & $49.05(24.99)$ & $49.07(100)$ \\
\hline
\end{tabular}

Values are mean \pm SEM, $n=192, A=$ Modern Market community, $B=$ North bank community, $C=$ Kanshio community, $D=$ Fiidi community

areas is shown in Table-5. It reveals that location, type of well, and a combination of these factors were all significant predictors of the MPN index and coliform count in the water. However, seasonality was not a significant predictor. In respect of the locations, the MPN index in Location A (54.8073) was significantly higher than in Locations B (42.6979), C (36.7396), and $\mathrm{D}$ (30.9427). The index in Location $\mathrm{C}$ seems to be similar to those in Locations B and D, but the MPN index in Location B was significantly higher than in Location D. Concerning the wells, the MPN index in NCW (72.4219) was significantly higher than in CCW (59.6250), BBW (49.0521), and BH (15.1719). The index in CCW was also significantly higher than in BBW and BH while the MPN index of BBW was also significantly higher than the $\mathrm{BH}$. The seasonal variation of MPN index in water was the same. The coliform count in Location A (57.9635) was significantly higher than in Locations B (50.0521), C (46.4323), and D (41.8229). The count in Location B was also significantly higher than in Locations $\mathrm{C}$ and $\mathrm{D}$ and Location $\mathrm{C}$ had significantly higher coliform than Location D. NCW (67.6458) recorded significantly coliform count than in BBW (48.3333), CCW (39.1094), and BH (10.099). The coliform count in BBW was also significantly higher than in $\mathrm{CCW}$ and $\mathrm{BH}$ while $\mathrm{CCW}$ also recorded significantly higher coliform count than BH. There was similar season variation of coliform counts in water samples.

\section{Discussion}

The result of fecal bacteria enumeration (MPN/100 mL) in water sample drawn from the study area by MPN index (Table-1) shows that with respect to settlement, in reducing order, it was highest in settlement; A (54.807) > B (42.679) > C (36.740) > D (30.943). With regard to the type of well (Table-5), the MPN index was in diminishing order of NCW (67.65) $>$ BBW (48.3) $>$ CCW (39.11) > BH (10.10). The high levels of the MPN index in all the wells in the locations covered by the study are above the WHO permissible limit of 2.2/100 $\mathrm{ml}$ [1]. The presence of these bacteria may be as a result of human and animal contamination from open defecation transported through overland flow into the wells or through flooding of suck away pits. The presence of these bacteria is of serious public health concern, but a lack of epidemic among the population consuming the water might be indicative that the bacteria are not pathogenic or the inhabitants have developed immunity to them. According to World Health Organization and UNICEF, Nigeria Equity Reports [1,2], coliform concentration signifies the presence of pathogenic agents in water, which can pose a significant risk to individuals with compromised immunity to pathogens. The MPN index in this study is higher than the values reported by Ocheri et al. [12] for one of the locations covered by this study. The values are similar to those reported by previous studies $[10,15,17]$ for different locations in Nigeria.

The seasonal variation in the MPN index in terms of wet and dry season showed more count during the wet season (41.48) than in the dry season (38.33), and this is expected as the bacteria are mostly transported in water which is most abundant in the wet season and the wet season temperature favors their growth with the appropriate temperature. This result collaborates with the result of previous studies $[15,17]$ who reported a higher MPN index during the wet season than the dry season.

The average coliform count $\left(\mathrm{CFU} \times 10^{5}\right)$ for the water samples of the wells was in significant decreasing order of NCW (72.42) > BBW (59.63) $>$ CCW (49.05) > BH (15.17) in Locations A (57.963) > B $(50.052)>(46.432)>(44.823)$, respectively. These values exceeded the WHO permissible limit for coliform count in drinking water [1]. The wet season also had more significant $(p<0.05)$ coliform count than the dry season, which is in consistent with the previous studies $[11,17]$ whom reported higher coliform count during the wet season than in the dry season.

\section{Conclusion}

The finding of this study shows the presence of both thermotolerant coliform and coliform bacteria isolates in all the wells and the $\mathrm{BH}$ in Makurdi exceeded the WHO permissible limits for drinking water. The water in these wells is, therefore, considered unsafe for domestic consumption due to the isolation of thermotolerant $E$. coli bacteria in them. There is the need to dose the wells with appropriate germicides to make them safe for drinking and the 


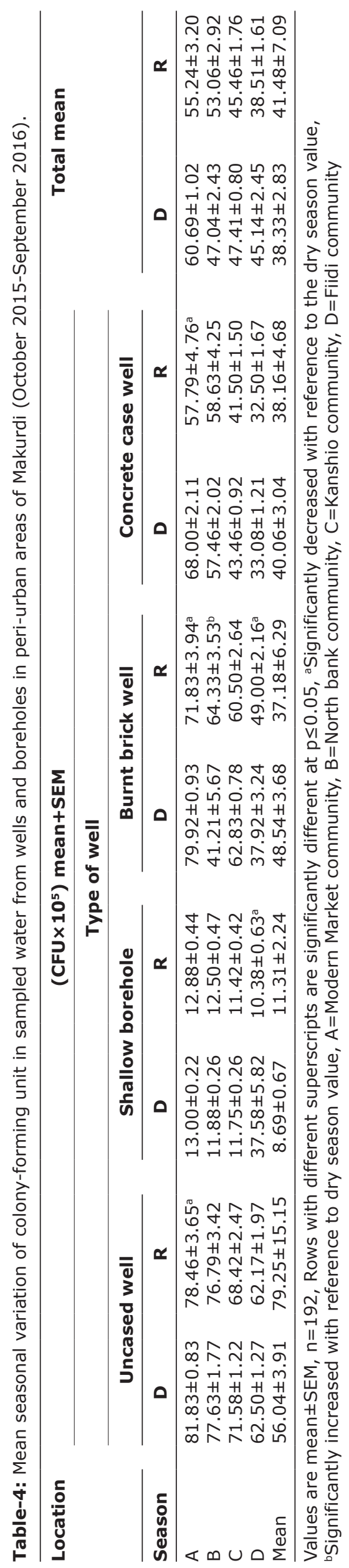

Table-5: Factors affecting the MPN index and colonyforming unit in sampled water from wells and boreholes in peri-urban areas of Makurdi (October 2015-September 2016).

\begin{tabular}{lcc}
\hline Factor & $\begin{array}{c}\text { MPN index } \\
(\mathbf{n} / \mathbf{n})\end{array}$ & $\begin{array}{c}\text { Colony-forming } \\
\text { unit }\left(\mathbf{C F U \times 1 0 ^ { 5 }}\right)\end{array}$ \\
\hline Location & & \\
A & $54.8073^{\mathrm{d}}$ & $57.9635^{\mathrm{d}}$ \\
B & $42.6979^{\mathrm{bc}}$ & $50.0521^{\mathrm{c}}$ \\
C & $36.7396^{\mathrm{cd}}$ & $46.4323^{\mathrm{b}}$ \\
D & $30.9427^{\mathrm{d}}$ & $41.8229^{\mathrm{a}}$ \\
Type of well & & \\
BH & $15.1719^{\mathrm{a}}$ & $10.0990^{\mathrm{a}}$ \\
CCW & $49.0521^{\mathrm{b}}$ & $39.1094^{\mathrm{b}}$ \\
BBW & $59.6250^{\mathrm{c}}$ & $48.3333^{\mathrm{c}}$ \\
NCW & $72.4219^{\mathrm{d}}$ & $67.6458^{\mathrm{d}}$ \\
Season & & \\
Dry & $38.33^{\mathrm{a}}$ & $50.07^{\mathrm{a}}$ \\
Rainy & $44.26^{\mathrm{a}}$ & $48.07^{\mathrm{a}}$ \\
\hline
\end{tabular}

Columns with any similar superscripts are not significantly different at $p \leq 0.05$

processing of food. Solar disinfection technologies are becoming popular and promising as they alleviate the concerns associated with the use of chemicals with long-term residual effects and reduce the pressure on fuel wood used for boiling water to disinfect it. There is also the need for advocacy and sensitization of the population on the water quality and the actions they can take to make the water safe for domestic use.

\section{Authors' Contributions}

RAO and AEJO conceived the idea and provided guidance and literature review. RAA conducted the research with the support of CAA who contributed in the laboratory analysis. RAA also wrote the initial draft and handled all correspondence with statistical imputes and suggestions from RAO and AEJO. All authors read and approved the final manuscript.

\section{Acknowledgments}

C.A. Akwuobu, College of Veterinary Medicine Federal University of Agriculture Makurdi, Nigeria. The authors did not receive any funds for this study.

\section{Competing Interests} interests.

The authors declare that they have no competing

\section{Publisher's Note}

Veterinary World (Publisher of International Journal of One Health) remains neutral with regard to jurisdictional claims in published map and institutional affiliation.

\section{References}

1. World Health Organization. (2017) Guidelines for Drinking Water Quality. World Health Organization, Geneva.

2. UNICEF, Nigeria Equity Reports. (2017) Health, HIV/ AIDS, Nutrition, Child Protection and WASH Programme. UNICEF, Nigeria Equity Reports, Abuja.

3. WaterAid. (2017) The State of the World's Water' Briefing Released to Mark World Water Day. Available 
from: http://www.wateraid.org/.../Nigeria/.../WaterAid _Nigeria_World_Water_Day_Release.pdf?1. Retrieved on 25-05-2018.

4. Shobowale, E.O., Adegunle, B. and Onyedibe, K. (2016) An assessment of hand hygiene practices of health care workers of a semi-urban teaching hospital using the five moments of hand hygiene. Niger. Med. J., 57(3): 150-154.

5. Nigeria Centre for Disease Control. (2018) Antimicrobial Use and Resistance in Nigeria: Situation Analysis and Recommendations. Nigeria Centre for Disease Control, Nigeria.

6. USAID. (2019) Nigeria Water. USAID, Nigeria. Available from: https://www.usaid.gov/nigeria/water. Retrieved on 12-07-2019.

7. Akaahan, T.J.A., Olabanji, F.M. and Azua, E.T. (2015) Studies on contamination of surface water of river Benue with trace elements at Makurdi, Benue State, Nigeria. J. Environ. Chem. Ecotoxicol., 7(5); 49-55.

8. National Population Commission. (2016) Projected Population for Makurdi, Benue State. National Population Commission, Abuja.

9. Ibaishwa, R.L. and Abaagu, A. (2018) Gender Access to Rural Water Supply, Sanitation and Hygiene in Rural Communities in Benue State, Nigeria. PAUWES Research2-practice Forum. Available from: https://ssrn.com/ abstract=3210631. Retrieved on 05-09-2019.

10. Terseer, E. and Ali, O.J. (2015) Effect of solid waste disposal on groundwater quality in Makurdi urban area of
Benue state, Nigeria. Asian Open Waste Manage. Tech. J., 1(2): 1-9.

11. Onajite, C.I., Onome, E.O., Oluwatoyin, F.I. and Alexander, O.E. (2018) Comparative microbial analysis of borehole water and other sources of water in Benin Metropolis, Edo State. J. Environ. Sci. Public Health, 2(2018): 232-242.

12. Ocheri, M.I., Odoma, L.A. and Umar, N.D. (2014) Groundwater quality in Nigerian urban areas. A review. Glob. J. Sci. Front. Res., 14(3): 102-111.

13. Adeiza, Z.O., Zakari, H.H. and Jere, S.A. (2018) Assessment of bacterial quality of some selected boreholes water in Kurnar Asabe Quaters Kano Metropolis. Ann. Microbiol. Infect. Dis., 1(2): 11-17.

14. Obioma, A, Chikanka, A.T. and Loveth, N.W. (2017) Evaluation of bacteriological quality of surface, well, borehole and river water in Khana local government area of Rivers State, Niger Delta. Ann. Clin. Lab. Res., 5(3): 183.

15. Izah, S.C., Kigigha, L.T. and Anene, E.K. (2016) Bacteriological quality assessment of Malus domestica Borkh and Cucumis sativus L. In Yenagoa Metropolis, Bayelsa state, Nigeria. Br. J. Appl. Res., 1(2): 5-7.

16. UNESCO (2017) Waste Water: Untapped Resource. U N World Water Development Report. Available from: https:// www.unwater.org/wwdr 2017. Retrieved on 05-09-2019.

17. Okunye, O.L. and Odeleye, F.O. (2016) Bacteriological investigation of well water samples from selected market locations in Ibadan Nigeria. Int. J. Pharm. Sci. Invent., 4(5): 32-36. 